\title{
PENGARUH PENGGUNAAN MODEL PROBLEM BASED LEARNING TERHADAP MINAT BELAJAR SISWA KELAS VII-B SMPN 1 KARANGJAYA
}

\author{
Odeh \\ SMP Negeri 1 Karangjaya, Jl. Sirnajaya, Tasikmalaya, Indonesia \\ Email: odeh199702@gmail.com
}

\begin{abstract}
Without embedding the learned concept has resulted in the fact that the students at SMPN 1 Karangjaya, especially grade VII B, still do not realize the existence of Indonesia's natural conditions. To overcome this problem , the writer tries to apply the problem based learning (PBL) model. Therefore, the purpose of this study is to determine the effect of using the Problem Based Learning (PBL) model to increase student interest in class VII B SMPN 1 Karangjaya on the material of Indonesia's natural conditions. The research subjects were the 24 students of SMPN 1 Karangjaya class VII $B$. This classroom action research uses three cycles, consisting of Cycle I, Cycle II and Cycle III. The findings of the study indicates that PBL can increase students' interest in learning the material of the Indonesia's natural conditions in three aspects. Firstly, the increase of cognitive aspects can be seen from cycle I to cycle II by $8.33 \%$, and cycle II to cycle III by $28.80 \%$. Secondly, the affective aspect can be seen from cycle I to cycle II by $18.06 \%$ and from cycle II to cycle III by $2.31 \%$. Thirdly, the of increase psychomotor aspects can be seen from cycle I to cycle II by $17.33 \%$ and from cycle II to cycle III by $9.34 \%$.
\end{abstract}

Keywords: Problem Based Learning Model, Learning Interest

\section{ABSTRAK}

Siswa di SMPN 1 Karangjaya khususnya kelas VII B masih belum memahami kondisi alam Indonesia. Salah satu penyebabnya adalah tidak tertanamnya konsep yang dipelajari pada diri siswa. Untuk mengatasi hal tersebut penulis mencoba menerapkan model Problem Based Learning (PBL). Oleh karena itu tujuan dari penelitian ini adalah untuk mengetahui pengaruh penggunaan model Problem Based Learning (PBL) terhadap peningkatan minat belajar siswa kelas VII B SMPN 1 Karangjaya pada materi kondisi alam Indonesia. Subjek penelitian adalah siswa di SMPN 1 Karangjaya kelas VII B dengan jumlah siswa 24 orang. Pelaksanaan penelitian tindakan kelas ini menggunakan tiga Siklus yaitu Siklus I, Siklus II dan Siklus III. Hasil dari penelitian diperoleh bahwa PBL dapat meningkatkan minat belajar siswa pada materi kondisi alam Indonesia. Peningkatan dalam aspek kognitif terlihat dari Siklus I ke Siklus II sebesar 8.33\%. Dan dari Siklus II ke Siklus III mengalami kenaikan sebesar 28,80\%. Peningkatan aspek apektif terlihat dari Siklus I ke Siklus II sebesar 18,06\% dan dari Siklus II ke Siklus III sebesar 2,31\%. Peningkatan aspek psikomotor terlihat dari Siklus I ke Siklus II sebesar 17,33\% dan dari Siklus II ke silkus III sebesar 9,34\%.

Kata Kunci: Model Problem Based Learning, Minat Belajar

Cara sitasi: Odeh. (2021). Pengaruh penggunaan model problem based learning terhadap minat belajar siswa kelas vii-b smpn 1 karangjaya. J-KIP (Jurnal Keguruan dan IImu Pendidikan), 2 (2), 9-14. 


\section{PENDAHULUAN}

Mata pelajaran IImu Pengetahuan Sosial adalah mata pelajaran yang berhubungan erat dengan kehidupan sehari hari siswa, salah satu materi yang di pelajari adalah tentang kondisi alam Indonesia. Setelah siswa mempelajari konsep tersebut, siswa diharapkan dapat memahami konsep tentang kondisi alam Indonesia. Harapan tersebut belum dapat terpenuhi oleh siswa di SMPN 1 Karangjaya, terbukti masih banyak siswa khususnya kelas VII B, umumnya siswa di SMPN 1 Karangjaya yang masih belum memahami terhadap keberadaan kondisi alam Indonesia. Salah satu penyebabnya menurut pengamatan penulis adalah tidak tertanamnya konsep yang dipelajari pada diri siswa. Untuk mengatasi hal tersebut, penulis mencoba menerapkan model Problem Based Learning (PBL) dalam menyampaikan konsep kondisi alam Indonesia. Sejalan dengan pendapat Agustiany, Hardi \& IImiati (2021) yaitu untuk mencapai keberhasilan dalam proses pembelajaran salah satunya yaitu dengan cara pemilihan media pembelajaran yang tepat dan tentunya sesuai dengan konsep mata pelajaran yang akan disampaikan oleh guru.

Problem Based learning (PBL) adalah salah satu model pembelajaran yang menggunakan masalah nyata yang tidak terstruktur dan bersifat terbuka sebagai konteks atau sarana bagi siswa untuk mengembangkan cara berfikir kritis, mengembangkan keterampilan dan menyelesaikan masalah serta membangun pengetahuan baru. Model pembelajaran PBL memiliki karakteristik berfokus terhadap permasalahan, siswa dituntut untuk berkomunikasi secara ilmiah, serta mendorong kemampuan memecahkan masalah siswa secara berkelompok (Shoimin, 2014). Dalam proses pembelajaran yang menggunakan model Problem Based Learning siswa secara individual maupun kelompok menyelesaikan masalah nyata dengan menggunakan strategi atau pengetahuan yang telah dimiliki, proses tersebut memungkinkan siswa berlatih mengembangkan kemampuan berpikir kritis dan kemampuan menyelesaikan masalah serta membangun konsep, pengetahuan serta strategi tertentu yang menekankan siswa untuk secara aktif membangun pengetahuannya sendiri bukan menerimanya dalam bentuk jadi dari guru.

Dengan menggunakan model Problem Based Learning minat siswa untuk mempelajari suatu konsep akan lebih meningkat, minat tersebut akan mempengaruhi hasil belajar siswa, sebab siswa akan mudah mengingat apa yang dipelajarinya. Minat belajar adalah suatu rasa lebih suka serta rasa ketertarikan kepada suatu hal atau aktivitas tertentu, tanpa ada yang menyuruh atau paksaan (Slameto, 2015).

Mengingat materi kondisi alam Indonesia merupakan salah satu materi yang dekat dengan kehidupan siswa dan perlu aplikasi atau penerapan dalam kehidupan sehari- hari, maka model problem based learning ( $P B L$ ) sangat cocok untuk dijadikan solusi dalam menyampaikan konsep tersebut sehingga minat belajar siswa akan meningkat. Sesuai dengan hasil penelitian dari Asnita (2019) yang hasil penelitiannya menunjukkan ada pengaruh model pembelajaran Poblem Based Learning dilengkapi kartu soal terhadap minat belajar siswa materi ikatan kimia di SMK Muhammadiyah Cerenti.

Berdasarkan latar belakang tersebut maka tujuan dari penelitian tindakan kelas ini adalah untuk mengetahui pengaruh penggunaan model Problem Based Learning (PBL) terhadap peningkatkan minat belajar siswa kelas VII B SMPN 1 Karangjaya pada materi kondisi alam Indonesia.

\section{METODE PENELITIAN}

Penelitian ini dilakukan di SMP Negeri 1 Karangjaya yang berlokasi di Jalan Sirnajaya Desa Karangjaya Kecamatan Karangjaya Kabupaten Tasikmalaya. Subjek penelitian pada penelitian tindakan kelas ini adalah siswa di SMPN 1 Karangjaya kelas VII B dengan jumlah siswa 24 orang yang terdiri dari 14 orang laki-laki dan 10 orang perempuan semester ganjil tahun pelajaran 2018/2019 pada mata pelajaran IPS terpadu. 
Pelaksanaan penelitian tindakan kelas ini menggunakan tiga Siklus yaitu Siklus I, Siklus II dan Siklus III. Teknik analisis data adalah sebagai berikut:

a. Data yang diperoleh dari hasil tes kognitif siswa dibandingkan dengan kriteria ketuntasan minimal yang sudah ditetapkan di SMPN 1 Karangjaya untuk tahun pelajaran 2018/2019 semester ganjil yakni 75 , jika hasil tes siswa sama, atau lebih dari nilai KKM maka siswa dinyatakan tuntas dan jika kurang dari nilai KKM maka dinyatakan tidak tuntas.

b. Jumlah siswa yang dinyatakan tuntas diprosentasekan, prosentasenya dibandingkan dengan kriteria keberhasilan setiap Siklus yang sudah ditentukan dalam penelitian tindakan kelas ini.

c. Aspek sikap (Apektif) diobservasi menggunakan jurnal

d. Aspek keterampilan (psikomotor) diobservasi menggunakan rubrik penilaian psikomotor hasilnya diprosentasekan, diharapkan dari setiap aspek, siswa mencapai kriteria keberhasilan baik.

e. Mengukur minat peserta didik dengan menggunakan angket

Kriteria Keberhasilan siswa setiap aspek dalam setiap Siklus diuraikan sebagai berikut:

1. Aspek kognitif

a. Siklus I dikatakan berhasil apabila 50\% siswa mencapai nilai sesuai dengan KKM.

b. Siklus II dikatakan berhasil apabila $60 \%$ siswa mencapai nilai sesuai dengan KKM.

c. Siklus III dikatakan berhasil apabila $75 \%$ siswa mencapai nilai sesuai dengan KKM..

2. Aspek apektif (sikap)

a. Siklus I dikatakan berhasil apabila dari semua aspek yang di observasi salah satunya ada yang mencapai kriteria cukup.

b. Siklus II dikatakan berhasil apabila dari semua aspek yang di observasi salah satu aspek mencapai kriteria baik.

c. Siklus III dikatakan berhasil apabila dari semua aspek yang di observasi dua aspek mencapai kriteria baik.

3. Keterampilan

a. Siklus I dikatakan berhasil apabila dari semua aspek keterampilan yang diobservasi salah satu aspek mencapai kriteria baik.

b. Siklus II dikatakan berhasil apabila dari semua aspek keterampilan yang diobservasi dua aspek mencapai kriteria baik.

c. Siklus III dikatakan berhasil apabila dari semua aspek keterampilan yang diobservasi tiga aspek mencapai kriteria baik

Dengan kriteria keberhasilan sebagai berikut:

$$
\begin{aligned}
& 81 \text { - } 100 \text { baik sekali } \\
& 66-80 \text { baik } \\
& 56-65 \text { cukup } \\
& 41-55 \text { kurang } \\
& 0-40 \text { gagal }
\end{aligned}
$$

\section{HASIL DAN PEMBAHASAN}

Penelitian ini menggunakan 3 Siklus yaitu Siklus I, Siklus II dan Siklus III. Ketiga Siklus tersebut terdiri dari Perencanaan, Pelaksanaan, Pengamatan, dan Refleksi. Pada kegiatan pembelajaran Siklus I materi yang dibahas adalah Kondisi Geologi Indonesia yag dilaksanakan pada tanggal 11 September 2018 dengan alokasi waktu (2x40) jam ke 1-2. Kemudian Siklus II dilaksanakan pada tanggal 12 September 2018 dengan alokasi waktu (2x40) jam ke 1-2 dengan materi Bentuk Muka Bumi dan Kondisi Iklim Indonesia. Selanjutnya Siklus III yang pelaksanaan pembelajarannya dilaksanakan pada tanggal 18 September 2018 dengan materi Persebaran Fauna di Indonesia. 
Seperti yang telah dipaparkan bahwa pelaksanaan penelitian tindakan kelas dilakukan sebanyak 3 Siklus yang dilihat dari 3 aspek yaitu kognitif, apektif dan psikomotor serta hasil angket siswa untuk mengukur minat belajar. Hasilnya adalah sebagai berikut:

1. Aspek kognitif

Siklus I dari 24 orang siswa yang tuntas sebanyak 13 orang atau $54.17 \%$ sedangkan yang tidak tuntas sebanyak 11 orang atau $45.83 \%$. Siklus II yang tuntas sebanyak 15 orang atau $62,50 \%$ sedangkan yang tidak tuntas sebanyak 9 orang atau sebesar $37,50 \%$, berarti dari Siklus I ke Siklus II aspek kognitif mengalami kenaikan sebesar 8.33\%. Pada saat Siklus III seorang siswa tidak hadir dengan alasan sakit. Yang tuntas mengalami kenaikan sebesar 28,80\% yaitu menjadi $91,30 \%$.

2. Aspek apektif

Penilaian sikap dilakukan dengan menggunakan jurnal dan daftar isian berupa angket, hasilnya adalah sebagai berikut: Siklus I aspek suasana pertemuan saat pembelajaran mencapai $63,89 \%$, aspek topik yang dibahas mencapai $47,22 \%$ dan kegiatanyang diikuti mencapai $45,83 \%$, di Siklus II suasana pertemuan saat pembelajaran mencapai $76,39 \%$, topik yang dibahas mencapai $68,06 \%$ dan kegiatan yang diikuti mencapai $66,67 \%$. Sedangkan Siklus III suasana pertemuan mencapai $76,39 \%$, topik yang dibahas mencapai $70,83 \%$ dan kegiatanyang diikuti mencapi $70.83 \%$. Melihat perolehan prosentase setiap aspek dari Siklus I ke Siklus II dan dari Siklus II ke Siklus III setiap aspek mengalami kenaikan. Sementara aspek apektif berupa jurnal dalam setiap Siklus mengalami penurunan sifat negatif siswa dan berubah menjadi sifat yang bersifat positif.

3. Aspek psikomotor

Aspek psikomotor dinilai dari pelaksanaan presentasi hasil kerja kelompok, hasilnya adalah sebagai berikut: kebenaran isi Siklus I mencapai 66.66\%, Siklus II mencapai $86.66 \%$, Siklus III mencapai 93.33\%. Kejelasan suara Siklus I mencapai 53.33\%, Siklus II mencapai 66.66\%, Siklus III mencapai $73.33 \%$. Keruntutan penyampaian Siklus I mencapai $53.33 \%$, Siklus II mencapai $66.66 \%$, Siklus III mencapai $86.66 \%$. Kemampuan dalam menanggapi pertanyaan Siklus I mencapai $60,00 \%$, Siklus II mencapai $80,00 \%$, Siklus III mencapai $86.66 \%$. Kerjasama dalam menanggapi pertanyaan Siklus I mencapai $53.33 \%$, Siklus II mencapai $73.33 \%$, Siklus III mencapai $80,00 \%$.

Ketiga aspek yang diamati selama penelitian tindakan kelas kenaikannya dapat dilihat dalam Tabel 1.

Tabel 1. Tabel kenaikan aspek kognitif,apektif dan psikomotor tiap Siklus

\begin{tabular}{|c|c|c|c|c|}
\hline No & Aspek & Siklus I & Siklus II & Siklus III \\
\hline \multirow{2}{*}{1.} & Kognitif & & & \\
\hline & - Tuntas & $54,17 \%$ & $62,50 \%$ & $91,30 \%$ \\
\hline & Apektif & & & \\
\hline \multirow{3}{*}{2.} & $\begin{array}{l}0 \text { Suasana pertemuan saat } \\
\text { pembelajaran }\end{array}$ & $63.89 \%$ & $76,39 \%$ & $76.39 \%$ \\
\hline & o Topik yang dibahas & $47,22 \%$ & $68,06 \%$ & $70.83 \%$ \\
\hline & o Kegiatan yang diikuti & $45,83 \%$ & $66,67 \%$ & $70.83 \%$ \\
\hline \multicolumn{2}{|c|}{ Rata-rata } & $52,31 \%$ & $70,37 \%$ & $72,68 \%$ \\
\hline \multirow{3}{*}{3.} & Psikomotor & & & \\
\hline & o Kebenaran isi & $66.66 \%$ & $86.66 \%$ & $93.33 \%$ \\
\hline & o Kejelasan suara & $53.33 \%$ & $66.66 \%$ & $73.33 \%$ \\
\hline
\end{tabular}




\begin{tabular}{lccc} 
0 Keruntutan penyampaian & $53.33 \%$ & $66.66 \%$ & $86.66 \%$ \\
$\begin{array}{l}\text { O Kemampuan menanggapi } \\
\text { pertanyaan }\end{array}$ & $60.00 \%$ & $80.00 \%$ & $86.66 \%$ \\
$\begin{array}{l}\text { O Kerjasama dalam mnanggapi } \\
\text { pertanyaan }\end{array}$ & $53.33 \%$ & $73.33 \%$ & $80.00 \%$ \\
Rata-rata & $57.33 \%$ & $\mathbf{7 4 . 6 6 \%}$ & $\mathbf{8 4 . 0 0 \%}$ \\
\hline
\end{tabular}

Pada awal kegiatan pembelajaran siswa nampak kurang tertarik dengan tema yang di sampaikan, yaitu tentang kondisi alam Indonesia, minat sebagian siswa baru terlihat ketika disajikan tayangan tentang terjadinya gunung meletus. Di Siklus II di saat kegiatan awal minat siswa sudah terlihat berubah, siswa seperti ingin mengulang kembali apa yang telah dilakukan di Siklus I, saat dilakukan apersepsi dan disampaikan tujan pembelajaran mereka kelihatan sudah dapat menentukan langkah apa yang akan dilakukan. Dalam kegiatan Siklus III siswa bukan hanya terlihat minatnya sejak awal pembelajaran tetapi nampaknya sudah memahami apa yang harus dilakukan selama kegiatan proses pembelajaran. Model pembelajaran PBL dapat meningkatkan motivasi dan ketertarikan siswa terhadap pembelajaran karena siswa dapat merasakan manfaat menyelesaikan permasalahan dan mengaitkannya dengan kehidupan nyata (Al-Tabany, 2015).

Hasil penelitian ini sejalan dengan hasil penelitian Luftiana \& Irawati (2019) yaitu model pembelajaran PBL berpengaruh terhadap minat belajar siswa kelas vii pada materi pencemaran lingkungan di SMP Negeri 2 Srumbung. Sama halnya dengan penelitian yang dilakukan oleh Muhson (2009) yang memperoleh hasil penelitian bahwa model pembelajaran PBL dapat mempengaruhi minat belajar siswa.

\section{KESIMPULAN}

Berdasarkan hasil Penelitian Tindakan Kelas yang telah dilaksanakan, maka dapat disimpulkan sebagai berikut, Model Problem Based Learning dapat meningkatkan minat belajar siswa kelas VII B SMPN 1 Karangjaya semester ganjil tahun pelajaran 2018/2019 pada materi kondisi alam Indonesia, hal ini ditunjukkan melalui peningkatan pada beberapa aspek, diantaranya: peningkatan dalam aspek kognitif, dibuktikan dengan adanya peningkatan prosentase siswa yang mencapai KKM yaitu Siklus I sebesar $54,17 \%$, Siklus II sebesar $62,50 \%$ dan Siklus III sebesar 91,30\%. Dimana peningkatan terlihat dari Siklus I ke Siklus II sebesar 8.33\%. Dan dari Siklus II ke Siklus III mengalami kenaikan sebesar $28,80 \%$. Peningkatan aspek apektif selama siswa bekerja kelompok membuat laporan. Terlihat dari rerata dari Siklus I sebesar 52,31\%, Siklus II sebesar $70,37 \%$ dan Siklus III sebesar 72,68\%. Dimana peningkatan terlihatdari Siklus I ke Siklus II sebesar $18,06 \%$ dan dari Siklus II ke Siklus III sebesar 2,31\%. Peningkatan aspek psikomotor pada saat siswa melakukan presentasi hasil kerja kelompok. Pada Siklus I sebesar $57.33 \%$,, Siklus II sebesar $74.66 \%$ dan pada Siklus III menjadi $84.00 \% .84 .00 \%$. dimana peningkatan terlihat dari Siklus I ke Siklus II sebesar $17,33 \%$ dan dari Siklus II ke silkus III sebesar 9,34\%.

\section{REKOMENDASI}

Berdasarkan hasil penelitian pada pembelajaran IPS maka model Problem based Learning diharapkan diteliti pada mata pelajaran lain selain mata pelajaran IPS.

\section{UCAPAN TERIMA KASIH}

Penulis mengucapan terima kasih kepada N, Suryamah Sugiarsih, S.Pd. guru mata pelajaran IPS Terpadu kelas IX dan VIII yang berperan sebagai observer pada penelitian ini. Selanjutnya ucapan terima kasih ditujukan kepada subjek penelitian yakni siswa di SMPN 1 
Karangjaya kelas VII B dengan jumlah siswa 24 orang yang terdiri dari 14 orang laki-laki dan 10 orang perempuan semester ganjil tahun pelajaran 2018/2019 pada mata pelajaran IPS terpadu.

\section{DAFTAR PUSTAKA}

Agustiany, R., Hardi, E., \& IImiati, N. (2021). Perbedaan Hasil Belajar Kognitif Siswa melalui Penggunaan Media Audio Visual dan Media Peta Konsep pada Materi Ekosistem. J-KIP (Jurnal Keguruan dan IImu Pendidikan), 2 (1), 15-20

Al- Tabany , T. I. B. (2015). Mendesain model pembelajaran inovatif, progresif, dan kontekstual. Jakarta: Prenada Media.

Asnita. (2019). Pengaruh model pembelajaran problem based learning dilengkapi media kartu soal terhadap minat belajar siswa pada materi ikatan kimia di smk muhamadiyah cerenti. Jurnal Online Mahasiswa FTK UNIKS, 1 (1), 61-65.

Luftiana, F., \& Irawati, H. (2019). pengaruh model pembelajaran pbl terhadap minat dan hasil belajar level c1-c4 siswa kelas vii smpn 2 srumbung materi pencemaran lingkungan. Prosiding Symbion (Symposium on Biology Education). Universitas Ahmad Dahlan.

Muhson, A. (2009). Peningkatan minat belajar dan pemahaman mahasiswa melalui penerapan problem based learning. Jurnal Kependidikan Penelitian Inovasi Pembelajaran, 39 (2), 171 182.

Shoimin, A. (2014). 68 model pembelajaran inovatif dalam kurikulum 2013. Yogyakarta: Ar-Ruzz Media.

Slameto. (2015). Belajar dan faktor-faktor yang mempengaruhinya. Jakarta: Rineka cipta. 